This is an Accepted Manuscript of an article published by Taylor \& Francis in Journal of Psychology on 07/01/19, available online:

https://tandfonline.com/doi/abs/10.1080/00223980.2018.1508401?journalCode=vjrl20 
Mitigating the harmful effect of perceived organizational compliance on trust in top management: Buffering roles of employees' personal resources

\author{
Dirk De Clercq \\ Goodman School of Business \\ Brock University \\ 500 Glenridge Avenue \\ St. Catharines, Ontario L2S 3A1 \\ Tel: +1 9056885550 x5072 \\ ddeclercq@brocku.ca \\ Dave Bouckenooghe \\ Goodman School of Business \\ Brock University \\ 500 Glenridge Avenue \\ St. Catharines, Ontario L2S 3A1 \\ Tel: +1 9056885550 x3901 \\ dbouckenooghe@brocku.ca
}

Paper accepted for The Journal of Psychology: Interdisciplinary and Applied

July 31, 2018 


\title{
Mitigating the harmful effect of perceived organizational compliance on trust in top management: Buffering roles of employees' personal resources
}

\begin{abstract}
This study considers how employees’ perceptions of organizational compliance—-defined as their beliefs that the organizational climate stifles change and values compliance with the status quo-reduce their trust in top management, as well as how this negative relationship might be buffered by access to two personal resources that support organizational change: openness to experience and affective commitment to change. Data from a sample of Pakistan-based organizations reveal that perceptions of organizational compliance reduce trust in top management, but this effect is weaker at higher levels of openness to experience and affective commitment to change. These findings are significant in that they indicate that employees who operate in organizational climates marked by “yea-saying” can counter the difficulty of improving their job situation by drawing from adequate personal resources.
\end{abstract}

Keywords: trust in top management; organizational politics; openness to experience; affective commitment to change; job demands-resources model 


\section{Introduction}

Organizational scholarship acknowledges the importance of developing trusting relationships between employees and organizational authorities (Clapp-Smith, Vogelgesang, \& Avey, 2009; Zhang, Tsui, Song, Li, \& Jia, 2008). In particular, employees’ high levels of trust in top management-defined herein as the extent to which they believe that their organization's senior decision makers are dependable and open in their communication and thus care for their well-being (Bouckenooghe, 2012; Bouckenooghe \& Menguc, 2016; Lee, Kim, Kim, Kwon, \& Cho, 2013) — is a significant manifestation of how they feel about their employment situation (Kramer, 1999; Mahajan, Bishop, \& Scott, 2012). For example, when employees express high levels of trust in top management, their organizational commitment (Mahajan et al., 2012) and work engagement (Chughtai \& Buckley, 2013) increase, and they are more likely to engage in productive behaviors such as innovation (Michaelis, Stegmaier, \& Sonntag, 2009) and to pursue their organization’s goals (Thomas, Zolin, \& Hartman, 2009). In contrast, a lack of trust in top management contributes to increased feelings of burnout, stress, and job dissatisfaction (Lambert, Hogan, Barton-Bellessa \& Jiang, 2012; Liu, Siu, \& Shi, 2010). Organizations thus have a critical need to understand which factors might inhibit the development of trust between employees and top management.

Previous research mostly emphasizes how positive contextual forces shape employees’ trust in top management, such as leader-membership exchanges (van Dam, Oreg, \& Schyns, 2008), perceived organizational support (Webber, Bishop, \& O’Neill, 2012), perceived justice (Colquitt \& Rodell, 2011; Wu, Huang, Li, \& Liu, 2011), acceptable performance appraisal systems (Mayer \& Davis, 1999), or the possibility to voice opinions about the organization’s internal functioning (Holland, Cooper, Pyman, \& Teicher, 2012). To extend research beyond 
these facilitators of trust, we investigate how dysfunctional political climates-that is, organizational climates that discourage change and personal initiative, and thereby curtail opportunities for learning and personal development (Byrne, 2005; Kacmar \& Baron, 1999)_might diminish trust in top management, as well as how personal resources might mitigate this effect. Doing so reflects our acknowledgment that employee-top management relationships are inherently asymmetric, and employees might experience significant stress if the organizational climate limits their ability to alter or improve their current job situations (Barry \& Wilkinson, 2016; Grimland, Vigoda-Gadot, \& Baruch, 2012; Hurley, 2006; Kacmar \& Baron, 1999).

Although an organizational climate that focuses on a strict adherence to the status quo might not always be negative, previous research emphasizes the dysfunctional character of organizational climates that reflect a "go-along-to-get-ahead" (i.e., GATGA) mentality. A climate anchored in a GATGA mentality embraces covert political behaviors that cause employees to become overly dependent on existing power structures (Byrne, 2005; O’Connor \& Morrison, 2001). In a “yea-saying” climate, employees often feel discouraged from speaking up about potential improvements in their work environment, even if doing so would benefit their performance outcomes and career development (Hochwarter, Witt, \& Kacmar, 2000). Perceptions of the presence of an organizational climate that values strong compliance with the status quo—-for parsimony, we use the term “perceptions of organizational compliance” or POC—are a significant source of stress for employees, because such beliefs prevent them from improving their job situation and thwart their personal growth (Byrne, 2005; Grimland et al., 2012; Magner \& Staley, 2014).

To substantiate our arguments about the relationship between employees’ POC and their trust in top management, as well as identify conditions in which POC might be less harmful, we 
draw from the job demands-resources (JD-R) model (Bakker \& Demerouti, 2007). This model proposes that stressful work conditions steer employees away from positive attitudes toward their employer, but access to relevant resources can buffer or mitigate this process (Bakker \& Demerouti, 2007; Crawford, LePine, \& Rich, 2010; Hakanen, Schaufeli, \& Ahola, 2008). Accordingly, when employees believe that the organizational climate favors compliance over personal initiative, they might become so concerned about their limited ability to improve their job situation that they perceive their organization's senior leadership as untrustworthy and not interested in their well-being (Byrne, 2005; Kacmar \& Baron, 1999).

Moreover, we argue that this negative process may be less prominent to the extent that employees can rely on two critical personal resources that stimulate organizational change: their openness to experience and affective commitment to change. Openness to experience is a personality trait that reflects the tendency of employees to seek out new, varied experiences (McCrae \& Costa, 1997). Among the Big Five personality traits, this one speaks most directly to employees’ ability to come up with novel ideas and solutions to address constraining organizational climates that discourage personal initiative (Baer \& Oldham, 2006; McCrae, 1984). Affective commitment to change instead captures employees’ beliefs about the intrinsic value of organizational change (Herscovitch \& Meyer, 2002) and the positive emotions that employees might experience in response to changes to the organizational status quo (Kabanoff, Waldersee, \& Cohen, 1995). Although employees marked by high levels of affective commitment to change might feel some frustration in organizational climates that stifle initiative, the argument advanced in this article, as informed by the JD-R model (Bakker \& Demerouti, 2007), is that the positive change-related energy that gets generated by this personal resource (Choi, 2011) might help employees overcome the stress invoked by such climates, such that they 
maintain some level of trust in top management. Further, in contrast with previous studies that examine how openness to experience might influence employees’ attitudes toward change, and particularly reduce their resistance to it (Saksvik \& Hetland, 2009), we focus on the concurrent roles of their openness to experience and affective commitment to change in shaping their reactions to POC.

These two personal resources, conceptualized as moderators in our proposed model, align with the logic of the JD-R model, according to which access to relevant resources provides employees with the energy needed to maintain positive work attitudes, despite the presence of workplace adversity (Bakker \& Demerouti, 2007; Pooja, De Clercq, \& Belausteguigoitia, 2016). In particular, the glue that binds the two resources is that they both instill positive change-related energy in employees, such that they increase the ability to mitigate the stress that comes with organizational environments that stifle employee initiative and critical thinking (Quinn, Spreitzer, \& Lam, 2012). They both might help employees overcome the limitations that surround an organizational climate that thwarts change and supports a GATGA mentality. Moreover, both resources complement each other: Openness to experience is a personality trait that captures employees’ natural tendency and associated cognitive ability to try new things and find creative ways to deal with adverse work situations (McCrae \& Costa, 1997), and affective commitment to change is an individual state-like characteristic that reflects the intrinsic value that employees assign to organizational changes (Choi, 2011). ${ }^{1}$ The combined consideration of these two contingency factors therefore provides a consistent, comprehensive approach to determine how employees’ resource access may buffer against the likelihood of distrust in top management when rigid organizational climates discourage change (Bakker \& Demerouti, 2007).

\footnotetext{
${ }^{1}$ The affective dimension of commitment to change contrasts with its normative and continuance counterparts, which reflect a sense of obligation to support organizational change and a recognition of the potential costs when the change is not supported, respectively (Herscovitch \& Meyer, 2002).
} 
The contribution of this study is multifold. First, extant research has paid little attention to how employees' trust in top management might be hampered by perceptions of covert political behaviors that thwart personal initiative and change. Instead, organizational change studies typically focus on outcomes, highlighting, for example, how trust in top management can stimulate employees’ support for change (Michaelis et al., 2009; van Dam et al., 2008). We propose that perceptions about whether the organizational climate supports change in themselves might be significant drivers of trust in top management. Second, previous research has not considered how the translation of dysfunctional organizational politics into lower trust in top management may be mitigated by employees’ access to personal resources (Byrne, 2005). This significant oversight prevents organizations from fully understanding how negative reactions (i.e., reduced trust in top management) to climates that prioritize compliance over speaking up might be contained by relevant individual characteristics. By studying the contingent factors of openness to experience and affective commitment to change, we consider how employees' access to two relevant personal resources can buffer or diminish the likelihood that they experience negative feelings about their employer in response to a compliance-oriented climate (Schaufeli \& Bakker, 2004), and we also respond to calls to apply contingency approaches to study the outcomes of destructive political behaviors (Chang, Rosen, Siemieniec, \& Johnson, 2012; Chen \& Fang, 2008; Miller, Rutherford, \& Kolodinsky, 2008). Third, the JD-R framework is useful for investigating the negative impact of adverse work conditions on employees' feelings about their organization (e.g., Crawford et al., 2010; Pooja et al., 2016). However, to the best of our knowledge, it has not been applied to important questions about how and when a compliance-oriented organizational climate might dampen employees' trust in top management. Thus, with this study, we extend the scope of the JD-R framework. 


\section{Theoretical Background}

Previous research extensively considers the question of why some employees express more or less trust in other organizational members (e.g., Colquitt, Scott, \& Lepine, 2007; Nienaber, Romeike, Searle, \& Schewe, 2015; Schoorman, Mayer, \& Davis, 2007). Trust has been conceptualized in various ways, including employees' willingness to be vulnerable to the actions of others (Colquitt et al., 2007; Rousseau, Sitkin, Burt, \& Camerer, 1998) or their belief that others will make good faith efforts to meet their commitments (Cummings \& Bromily, 1996). A critical aspect that binds these conceptualizations is the positive expectations that employees have, namely, that other members will act in reliable and consistent ways and are concerned about their well-being (Lewicki, Tomlinson, \& Gillespie, 2006; Nienaber et al., 2015).

With this study, we focus on employees' trust in top management, or the group of senior decision makers who operate at the top of the organizational chart (McCauley \& Kuhnert, 1992). The level of trust that employees have in organizational authorities influences other attitudes, such as their work engagement (Chughtai \& Buckley, 2013), and their behaviors, such as their innovative activities (Michaelis et al., 2009). Such elements in turn have direct implications for organizational performance. Consistent with previous research (Bouckenooghe, 2012; Korsgaard, Schweiger, \& Sapienza, 1995; Lee et al., 2013; Schoorman et al., 2007), we conceptualize trust in top management as the belief that the organization's senior leadership is consistent in its decision making, fulfills previously made promises, and adopts open communication practices—all features that reflect top management's benevolence or the extent to which it has employees' best interests at heart (Mayer, Davis, \& Schoorman, 1995; Schoorman et al., 2007). 
Previous research indicates that the trust that employees have in top management is mostly informed by their assessments of organization-wide processes and procedures, instead of characteristics of their interpersonal relationships with specific organizational members (McCauley \& Kuhnert, 1992; cf. Costigan, Insinga, Berman, Kranas, \& Kureshov, 2011). As we noted previously, extant studies of contextual influences highlight the enabling roles of positive factors, such as perceived organizational support (Webber et al., 2012), leader-member exchanges (van Dam et al., 2008), performance appraisals (Mayer \& Davis, 1999), and job involvement (Mahajan et al., 2012) in shaping employees’ trust in top management. In turn, relatively little attention has been devoted to the harmful effects that negative factors might play in inhibiting such trust, including the presence of an organizational climate that embraces destructive political behaviors (Chen \& Indartono, 2011; Nienaber et al., 2015). Yet such political behaviors constitute important realities that challenge effective organizational functioning (Blass, Brouer, Perrewe, \& Ferris, 2007; Grimland et al., 2012; Vredenburgh \& Shea-VanFossen, 2010). For example, dysfunctional political climates can lead to enhanced job stress and burnout (Valle \& Perrewé, 2000), reduce organizational commitment (Vigoda, 2000) and job satisfaction (Zhou \& Ferris, 1995), and increase uncertainty about whether work efforts generate positive performance outcomes (Cropanzano, Howes, Grandey, \& Toth, 1997). Destructive organizational politics also can inhibit positive organizational change, as manifested in fewer opportunities to voice opinions about how the organizational status quo can be improved (Li, Wu, Liu, Kwan, \& Liu, 2014), as well as lower creativity (Rosen, Ferris, Brown, Chen, \& Kim, 2014) and innovation (Frost \& Egri, 1991).

Notably, dysfunctional, politically oriented climates can take different forms. They are not restricted to overt, self-serving political behaviors, such as blatantly spreading negative 
rumors to achieve direct personal gains. Rather, they might entail obscure or hidden behaviors, such as when employees feel forced to align their opinions with those of senior decision makers (Byrne, 2005). We focus on this type of dysfunction and acknowledge that a significant manifestation of covert politics takes place when the organizational climate promotes strict compliance with the status quo (Kacmar \& Carlson, 1997). Such a climate can be stressful for employees, because it limits their ability to improve their job situation and learn from their efforts, thereby undermining their personal development (Li et al., 2014; Parker, Dipboye, \& Jackson, 1995). An organizational climate that supports GATGA behavior thus might be frustrating for employees, because it indicates that adherence to the status quo takes precedence over individual employee initiative or well-being (Espedal, 2017; Kacmar \& Baron, 1999).

To anchor our theoretical arguments about the negative relationship between perceptions of organizational compliance (POC) and trust in top management, we draw from the JD-R model (Bakker \& Demerouti, 2007). It predicts that adverse work conditions generate significant stress among employees, which can translate into negative attitudes toward the organization (Pooja et al., 2016). Furthermore, it postulates that workplace adversity has less harmful effects to the extent that employees have access to relevant resources, including those that they hold individually (Schaufeli \& Bakker, 2004; Schmitz \& Ganesan, 2014). That is, in the presence of relevant personal resources, stressful work conditions are less likely to turn into negative work attitudes, because the resources protect or buffer against this impact (Bakker \& Demerouti, 2007; Van Emmerik, Bakker, \& Euwema, 2009).

First, we argue that POC is a stressor that directly informs employees’ negative attitudes toward their organization's senior leadership. According to the JD-R model, job demands—such as unfavorable physical work conditions, excessive workloads, or unsupportive organizational 
climates—are energy draining and generate psychological costs for employees (Bakker \& Demerouti, 2007). Similarly, perceptions that it would be difficult to improve the current organizational situation, in response to an organizational climate that stifles personal initiative and focuses on the status quo, may be a significant source of stress that undermines employees' ability to find ways to meet their job requirements (Byrne, 2005; Kacmar \& Baron, 1999).

Second, we apply the buffering argument of the JD-R model (Bakker \& Demerouti, 2007) by predicting a mitigating effect of openness to experience and affective commitment to change on the negative influence of POC on trust in top management. Openness to experience, one of the Big Five personality traits (Barrick \& Mount, 1991), should have a beneficial effect in situations in which employees face constraining, initiative-thwarting work situations, by enabling them to try new methodologies and approaches (Keller \& Weibler, 2015). Affective commitment to change in turn captures employees' emotional buy-in and adherence to the idea that change is instrumental for improving the organization, even if the organizational climate might obstruct change (Herscovitch \& Meyer, 2002). The JD-R model thus offers a theoretical framework that advances not only our understanding of the negative outcomes of POC on trust in top management but also the buffering roles of these critical personal resources in this process, as we detail in the Hypotheses section.

[Insert Figure 1 about here]

\section{Hypotheses}

Perceptions of Organizational Compliance and Trust in Top Management

We predict a negative relationship between employees’ POC and their trust in top management. According to the JD-R model, adverse work situations are stressful and can lead to negative feelings toward the organization, because the situations deplete employees' positive 
energy reservoirs as they try to cope with the adversity (Hakanen et al., 2008; Pooja et al., 2016; Schaufeli \& Bakker, 2004). Similarly, when employees are convinced that the organizational climate favors compliance rather than personal initiative, they may experience significant frustration, because they feel constrained and fear that the climate will compromise their ability to improve their own job situation (Kacmar \& Ferris, 1991; Li et al., 2014). This fear then may lead to negative attitudes toward their organization's senior leadership, as reflected in low trust in top management, because employees are preoccupied with negative feelings of anxiety and worry about their organizational functioning (Bakker \& Demerouti, 2007; Mahajan et al., 2012). For example, an organizational climate that prefers yea-saying over speaking up may give employees the impression that top management is filtering out important information, because the climate discourages "rocking the boat” or speaking up about problem areas. These employees likely believe top management is not open to their communication, withholds crucial development opportunities, or undermines their ability to perform and develop themselves through their active contributions to organizational improvement (Byrne, 2005; Grimland et al., 2012; Kacmar \& Baron, 1999; Li et al., 2014; Rosen et al., 2014). Similarly, previous research on trust in top management shows that when employees are not allowed to be involved in their organization's decision-making process, their trust gets compromised, because they believe their organization's senior leadership does not value their opinions or care for their well-being (Mahajan et al., 2012). If instead they experience a climate that discourages blind compliance, employees should feel less stressed and believe that their organization can be counted on to support their endeavors to improve their current job situation, which leads to positive feelings of trust in their organization’s senior leadership (Bakker \& Demerouti, 2007; Mahajan et al., 2012). 
A climate that focuses on compliance with the status quo instead of personal initiative also might reduce trust in top management, because it can be interpreted as insensitive and disrespectful (Chang, Rosen, \& Levy, 2009; Ferris \& Kacmar, 1992). When employees experience stressful work conditions that discourage their attempts to take on existing power structures or question organizational malfunctions, they may experience strong animosity, or even anger, toward organizational authorities, because the organization's features undermine their ability to perform well or advance (Bakker \& Demerouti, 2007; Grimland et al., 2012; Kacmar \& Ferris, 1993). We therefore anticipate less trust in top management when employees have strong negative views about the organizational climate. Explicitly, if they perceive that the organizational climate emphasizes compliance with the status quo and discourages personal initiative, they may predict destructive managerial decision making (Bouckenooghe, 2012; Eisenhardt \& Bourgeois, 1988) and regard the setting as counterproductive or offensive. Ultimately, they would exhibit little trust that top management cares about their well-being. Hypothesis 1: There is a negative relationship between employees' perceptions of organizational compliance and their trust in top management.

\section{Moderating Role of Openness to Experience}

We predict a buffering effect of employees’ openness to experience on this negative relationship between their POC and trust in top management. According to the JD-R model, the harmful effect of work stressors diminishes when employees can draw from personal resources that help them undo the accompanying stress (Bakker \& Demerouti, 2007; van Doorn \& Hülsheger, 2015). Openness to experience means that employees are motivated to find creative ways to deal with negative organizational climates, such as those that do not grant them room to take personal initiative (McCrae \& Costa, 1997). This motivation may reduce or buffer the stress that stems from the adverse situation and diminish their propensity to distrust management 
(Bakker, Demerouti, \& Euwema, 2005). For example, suggestions about how to improve the current job situation may encounter great resistance from top management in a yea-saying climate, particularly if those suggestions undermine their personal turf (Chen, Liu, \& Tjosvold, 2005; Van Dyne, Ang, \& Botero, 2003). But employees with greater openness to experience are more likely to pursue novel ways to reduce such resistance and should be highly involved in such activities (George \& Zhou, 2001; McCrae \& Costa, 1997). Therefore, they might maintain some trust in top management, even in a compliance-oriented climate (Mahajan et al., 2012). Previous research similarly indicates that employees high on openness to experience express more curiosity about novel ways to deal with stressful work situations, which mitigates the uncertainty that arises in such situations (Baer \& Oldham, 2006).

Moreover, employees who score high on openness to experience may feel positively energized when confronted with work situations that run counter to their natural tendencies. In response, they may feel compelled to tackle these challenging situations, and executing job tasks in a compliance-oriented climate may provide some personal fulfillment (Keller \& Weibler, 2015; McCrae, 1987). In this sense, the personal resource of openness to experience might stimulate not just employees’ ability to address the negative consequences of covert political behavior but also the personal joy that they derive from this process (McCrae \& Costa, 1997), which ultimately should diminish the harm to their trust in top management (Mahajan et al., 2012). Conversely, employees who are not open to experience generally have less motivation to find novel solutions to challenging situations (Keller \& Weibler, 2015), so they allocate less energy to improving their job situation or personal development in a climate that emphasizes strict compliance with the status quo, which should diminish their trust in top management.

Hypothesis 2: The negative relationship between employees' perceptions of organizational compliance and their trust in top management is moderated by their 
openness to experience, such that the relationship is weaker at higher levels of openness to experience.

\section{Moderating Role of Affective Commitment to Change}

We predict a similar buffering role of affective commitment to change; employees who believe in the value of change should be better able to protect themselves against the stress that comes with an organizational climate that favors the status quo over personal initiative.

Employees who exhibit a strong belief in the value of change are more likely to reach out to peers and ask for their advice about how to improve their job situation in a climate that focuses on strict compliance with the status quo (Choi, 2011; Herscovitch \& Meyer, 2002). Consistent with the JD-R model, this advice might serve as a buffer that mitigates the frustration that results from such a climate (Bakker \& Demerouti, 2007; Byrne, 2005; Cohen \& Wills, 1985) and prevents employees from believing that their organization is withholding critical information from them. Enhanced information sharing with peers also can generate new insights into why the organizational climate might encourage yea-saying over personal initiative (Wanberg \& Banas, 2000). These insights then can help employees cope with the stress that comes with a constraining, compliance-oriented climate and maintain some trust in top management (Bakker

\& Demerouti, 2007). Similarly, previous research indicates that access to adequate information is beneficial for the development of trust in top management (Thomas et al., 2009). Thus, a strong affective commitment to change should mitigate the likelihood that POC translate into lower trust in top management, because the organizational environment is perceived as less harmful.

The frustration that employees feel when encountering an organizational compliance climate also might be contained more easily if they feel passionate about changing the situation, because they enjoy the challenge of finding solutions (Baum \& Locke, 2004; Choi, 2011). Affective commitment to change thus may attenuate the potency with which POC reduces trust 
in top management, because it increases the attractiveness of speaking out against such a climate (Rosen et al., 2014). Employees who feel committed to change also have a strong intrinsic motivation to exploit their skill set to deal with stressful work situations (Meyer \& Herscovitch, 2001; Neves \& Caetano, 2009), so positive feelings of accomplishment when they succeed in these endeavors may diminish the belief that top management is withholding critical information from them. Conversely, when employees are unconvinced of the value of change, they likely feel less excited or energized about opportunities to overcome a compliance-oriented climate (Wanberg \& Banas, 2000), so they may develop less positive feelings toward their organization’s senior leadership.

Hypothesis 3: The negative relationship between employees' perceptions of organizational compliance and their trust in top management is moderated by their affective commitment to change, such that the relationship is weaker at higher levels of affective commitment to change.

\section{Research Method}

Sample and Data Collection

We collected data for this study from two companies that participated in an executive training program at a leading business school in Lahore, Pakistan: a nonprofit organization active in the educational sector and a for-profit company in the textile sector. The data collection process involved two surveys, distributed in two waves with a time lag of two weeks, consistent with previous research (Bouckenooghe, De Clercq, \& Deprez, 2014; De Clercq, Haq, \& Azeem, 2018). The use of a time lag between the measurement of the dependent variable and independent variables is a standard procedure that alleviates potential common method variance (Podsakoff, MacKenzie, Lee, \& Podsakoff, 2003). Furthermore, the time lag was long enough to reduce concerns about reverse causality (e.g., high levels of trust in top management might 
generate positive feelings in employees about their organizational climate) but not so long that significant organizational events could have occurred during the research period.

The two surveys contained unique identification numbers, so we could match responses collected in each wave. A cover letter explained the purpose of the study and assured participants of the complete confidentiality of their responses, noting that the responses would be accessible only to the research team, no information at the individual level would ever be made public, and only aggregate data would be used in the research. Moreover, the surveys contained reassurances that there were no correct or incorrect answers, and we asked the respondents to answer the questions as honestly as possible. These measures helped diminish social desirability or acquiescence biases (Spector, 2006). The first survey assessed employees' POC, openness to new experiences, and opinions about change in the organization. The second survey then asked these same respondents to assess their trust in the organization's top management. Of the 350 surveys distributed, we received 164 completed pairs of surveys across the two data collection points, 112 for the educational organization and 52 for the textile company, resulting in an overall response rate of $47 \%$. The respondents were on average 39.62 years old and had worked for their organization for 9.85 years. $^{2}$

\section{Measures}

The measures of the focal constructs used items from previous research, with five-point Likert scales ranging from 1 ("strongly disagree”) to 5 ("strongly agree”). To assess how much trust employees have in their organization's top management, we applied a four-item scale

\footnotetext{
${ }^{2}$ An independent-samples t-test, which compared the respondents in the educational organization and textile company, indicated that there were no significant differences in employees' trust in top management (3.81 versus 3.93, respectively, $n s$ ) and affective commitment to change ( 4.10 versus $4.02, n s)$. Yet there were significant differences in employees' POC ( 2.75 versus $3.09, p<.01$ ), openness to experience (4.16 versus $3.90, p<.01$ ), age (43.85 versus 30.42 years, $p<.001$ ), and organizational tenure (12.64 versus 3.77 years, $p<.001$ ). In light of these differences in sample means for some variables, we included a dummy variable for organization type in the regression analyses.
} 
borrowed from previous research that emphasizes the importance of consistency and open communication (Bouckenooghe, 2012). Two example items are "Top management fulfills its promises" and "Top management keeps all departments informed about its decisions" $($ Cronbach's alpha $=.73)$. This measure captures the content domain of our conceptualization of trust in top management, namely, the extent to which employees believe that top management is dependable and transparent in its communication. It has robust psychometric properties (Bouckenooghe, Devos, \& Van den Broeck, 2009) and has been applied previously to study perceived organizational politics (Bouckenooghe, 2012).

We used the six-item go-along-to-get-ahead (GATGA) scale by Kacmar and Carlson (1997) to measure perceptions of organizational compliance. Previous research indicates that such perceptions can be treated as distinctive features of dysfunctional organizational politics, separate from the direct political behaviors that people use blatantly to advance themselves by tearing others down, as well as from political games played to earn pay or promotion benefits (Byrne, 2005; Kacmar \& Carlson, 1997). For example, items indicated, "It is best not to rock the boat in this organization" and "Sometimes it is easier to remain quiet than to fight the system" (Cronbach’s alpha $=.70)$.

For the moderators, we measured openness to experience with nine items from the Big Five personality traits inventory (John, Donahue, \& Knetle, 1991; Watson, Suls, \& Haig, 2002), such as, "I see myself as someone who is original" and "I see myself as someone who is curious about many different things" (Cronbach’s alpha $=.71){ }^{3}$ To measure affective commitment to

\footnotetext{
${ }^{3}$ We deleted one (reverse-coded) item from the ten-item scale, because the alpha value was below .70 (Nunnally, 1978) when we included it. This particular item had a corrected item-to-total correlation of .03, suggesting very little variance in common with the other items. A robustness check with a composite measure that included all 10 items generated results that were completely consistent with those reported in Table 2. The omission of unreliable items from scales measuring the Big Five inventory is consistent with previous research (e.g., Leung, Wong, Chan, \& Lam, 2013; Raja \& Johns, 2010; Spence, Owens, \& Goodyer, 2012).
} 
change, we used a six-item scale based on Herscovitch and Meyer (2002), capturing employees' perceptions of the intrinsic value of change. For example, the respondents indicated whether "I believe in the value of change" and "Change serves an important purpose" (Cronbach's alpha = .72). Consistent with previous research (Macky \& Boxall, 2007; Shen, Tang, \& D’Netto, 2014), we controlled for age and organizational tenure. We also controlled for organization type ( 1 = textile company; see Footnote 2).

\section{Results}

Preliminary Analyses

Before testing the hypotheses, we checked the appropriateness of the data for the analyses. First, because the responses included some missing data, we performed Little's test of whether data are missing completely at random (Little \& Rubin, 1989; Schafer, 1997); they were for our sample $\left(\Delta \chi^{2}(467)=439.75, p=.81\right)$. Moreover, the percentage of missing data equaled $1.50 \%$, below the $5 \%$ cut-off that marks inconsequential missing data (Schafer, 1999). We also replaced the missing values by applying the expectation maximization algorithm (Dempster, Laird, \& Rubin, 1977), which is an appropriate method for treating missing data, because the estimated parameters are consistent with missing-at-random conditions (Dempster et al., 1977; Little \& Schenker, 1995).

Second, we checked for multivariate normality with the standard normality test in AMOS, notwithstanding the argument that deviations from multivariate normality do not automatically affect the analysis results. For example, Arbuckle (1997, p. 239) argues that "a departure from normality that is big enough to be significant could still be small enough to be harmless." For our study, the critical ratios for the skewness and kurtosis of the openness to experience and affective commitment to change constructs were greater than the benchmark of 
\pm 2.0 , yet the value for the multivariate omnibus test was less than 2.0. According to the Mahalanobis d-squared values, 5 of the 164 observations were potentially problematic outliers that caused non-normality in our data. After removing these outliers, the critical ratios were lower than 2.0 in absolute value for each construct. Therefore, we tested the hypotheses using 159 responses, after excluding these outliers. An advantage of deleting the outliers, rather than an alternative approach of transforming the data, is that it retains the assumption of linearity (Gao, Mokhtarian, \& Johnston, 2014).

Third, we estimated a four-factor measurement model with confirmatory factor analysis (Anderson \& Gerbing, 1988). Although global fit indices such as the goodness-of-fit index and adjusted goodness-fit-index often serve to assess model fit, they also have been criticized (Hu \& Bentler, 1998). Instead, Hu and Bentler (1998) recommend the use of the incremental and confirmatory fit indices (IFI and CFI) or residual fit indices (e.g., standardized root mean residual [SRMR]) (Bentler, 1995; Joreskog \& Sorbom, 1986). Monte Carlo studies reveal that these fit indices offer more robust measures than their global fit counterparts (e.g., Fan, Thompson \& Wang, 1999; Hu \& Bentler, 1998; Jackson, 2007; Marsh, Balla, \& Hau, 1996). Moreover, the root mean square error of approximation (RMSEA) performs well in terms of providing an adequate model specification without being dependent on sample size (Jackson, Gillaspy, \& Purc-Stephenson, 2009). Our measurement model yielded an adequate fit, according to these preferred fit indices $\left(\chi^{2}(261)=347.19, \chi^{2} / \mathrm{df}=1.33, \mathrm{IFI}=.91, \mathrm{CFI}=.90, \mathrm{SRMR}=.07\right.$, RMSEA = .05; Bentler \& Bonnett, 1980; Yuan, 2005). ${ }^{4}$ Moreover, we found support for discriminant validity, because in each construct pair, there were significant differences between the chi-square values of the constrained models in which the correlations between the two

\footnotetext{
${ }^{4}$ Despite the relatively small sample size, the participant-to-item ratio met the rule of five $(159 / 26=6.12)$ (Bryant \& Yarnold, 1995).
} 
constructs were set to equal 1 and their unconstrained counterparts in which the correlations were set free $\left(\Delta \chi^{2}{ }_{(1)}>3.84\right.$; Anderson \& Gerbing, 1988).

Fourth, we performed two tests to check for common method bias. In Harman's singlefactor test (Podsakoff \& Organ, 1986), if common method bias exists, a single factor would account for most of the variance in the data. Our exploratory factor analysis instead indicated that the first factor accounted for only $16 \%$ of the variance. Next, the confirmatory factor analysis of a model in which we let each measurement item load on a single factor generated significantly worse fit than the fit of the four-factor model. The difference in the chi-square values of these two models was strongly significant $\left(\Delta \chi^{2}(38)=489.43, p<.01\right)$. This finding further alleviates concerns about common method bias. Previous research also shows that the risk of common method bias is substantially lower for theoretical models that include moderating effects, because it is more difficult for respondents to identify those effects (Brockner, Siegel, Daly, Tyler, \& Martin, 1997; Simons \& Peterson, 2000).

Hypothesis Tests

In Table 1, we present the zero-order correlations and descriptive statistics; in Table 2, we provide the regression results. Model 1 included the control variables, Model 2 added perceptions of organizational compliance (POC), and Model 3 added the two moderators of openness to experience and affective commitment to change. In Models 4 and 5, we added the POC $\times$ openness to experience and POC $\times$ affective commitment to change interaction terms, respectively. Previous research affirms that it is appropriate to add multiple interaction terms separately, because the simultaneous inclusion of multiple interaction terms into a single model can mask the true moderating effects (Aiken \& West, 1991; De Clercq, Bouckenooghe, Raja, \& 
Matsyborska, 2014; Zahra \& Hayton 2008). We mean-centered the variables before calculating the interaction terms (Aiken \& West, 1991).

[Insert Tables 1 and 2 about here]

In support of our baseline prediction in Hypothesis 1, that employees’ perceptions of a climate that favors compliance with the status quo generate negative feelings toward the employer, Model 2 reveals that POC relates negatively to trust in top management $(\beta=-.46, p<$ .001). Although not part of our theoretical framework, Model 3 also indicates a direct positive relationship between affective commitment to change and trust in top management $(\beta=.25, p<$ .05 ), whereas the link between openness to experience and trust in top management is not significant $(\beta=.11, n s)$.

Models 4 and 5 support the hypothesized buffering effects of openness to experience ( $\beta$ $=.40, p<.05)$ and affective commitment to change $(\beta=.51, p<.001)$ on the relationship between POC and trust in top management. That is, increasing the levels of POC has a smaller likelihood of diminishing trust in top management when employees are more open to trying new, varied experiences (Hypothesis 2) or express stronger beliefs about the intrinsic value of change for their organization (Hypothesis 3). To clarify the nature of these interactions, we plotted the effects of POC on trust in top management at high and low levels of the two moderators (Figures 2 and 3), combined with a simple slope analysis for each (Aiken \& West, 1991). The results of the simple slope analyses indicate that the relationship between POC and trust in top management is significant at low levels of both openness to experience $(\beta=-.84, p<.001)$ and affective commitment to change ( $\beta=-1.01, p<.001$ ) but not significant at high levels of these moderators $(\beta=-.05, n s ; \beta=.02, n s$, respectively), in further support of Hypotheses 2 and 3.

[Insert Figures 2 and 3 about here] 
In addition to assessing the statistical significance of the hypothesized effects, we checked their practical significance by calculating the corresponding semi-partial correlation coefficients (Aloe \& Becker, 2012). We found a semi-partial correlation coefficient of .40 for the main effect of POC in Model 2, then semi-partial correlation coefficients of .17 and .23 for the interaction effects of POC $\times$ openness to experience and POP $\times$ affective commitment to change in Models 4 and 5, respectively. These correlation coefficients indicate relatively low values for the amount of unique variance explained by these three factors - the value of .40 corresponds with $16 \%$ explained variance, the value of .17 with $3 \%$ explained variance, and the value of .23 with 5\% explained variance-yet they still are higher than the median correlational effect size of .16 that Bosco, Aguinis, Singh, Field, and Pierce (2015) found in their analysis of effect sizes in applied psychology research, so they can be considered medium in size. ${ }^{5}$ Moreover, in light of the critical importance of employees’ trust in top management, which deeply informs the extent to which they undertake positive work behaviors that add to organizational effectiveness (e.g., Michaelis et al., 2009; Thomas et al., 2009), even small effects still could have substantial practical relevance for organizations.

Even though the conceptual focus of this study is on the concurrent interplay of POC, openness to experience, and affective commitment to change in predicting trust in top management, we undertook a post hoc analysis that accounted for possible interdependencies among these constructs, such as the possibility that employees' affective commitment to change

\footnotetext{
${ }^{5}$ With data from 1,660 articles published in Journal of Applied Psychology and Personnel Psychology, Bosco et al. (2015) identified a median effect size - which they defined as the absolute value of the corresponding correlation coefficients—of .16 across 147,328 correlational effect sizes. They accordingly argued that correlational effect sizes that fall within the range from .10 to .39 are medium in size and generally acceptable. For correlational effects pertaining to relationships among attitudes specifically, as in our study, the interval that defines a medium effect size according to Bosco et al. (2015) was [.18, .39]. This interval encompasses the correlational effect sizes we found, with the slight exception of the .17 value for the POC $\times$ openness to experience interaction term, which is just below the lower bound of the interval. Overall, the effect sizes in this study, though somewhat relatively weak, therefore are not exceptionally low.
} 
might be influenced by their POC and their openness to experience. Accordingly, we ran two path models, corresponding with the two regression Models 4-5 in Table 2, that included covariances among POC, openness to experience, and commitment to change. The hypothesized effects were consistent with the results obtained from the regression analysis (Table 2); the main effect of POC and the moderating effects of openness to experience and affective commitment to change remained robust even after accounting for their possible causal interdependencies (De Clercq, Thongpapanl, \& Dimov, 2009). Finally, we checked an alternative model in which affective commitment to change served as a potential mediating variable, but we failed to find empirical support for this model, because bootstrapping generated a confidence interval for the indirect effect of POC on trust through affective commitment to change that included 0 ([-.853; .001], Preacher \& Hayes, 2004).

\section{Discussion}

Explaining why some employees are more likely than others to perceive their organization's senior leadership as trustworthy is an important endeavor, because such perceptions inform positive employee behaviors such as organizational goal accomplishment (Colquitt et al., 2007; Thomas et al., 2009) and innovation implementation efforts (Michaelis et al., 2009). This study contributes to extant research by elaborating on how employees' perceptions of organizational compliance (POC) might lead to lower levels of trust in top management, as well as how their personal resources may function as buffers in this process. The relatively limited attention to this issue is surprising, in light of the argument that frustration with dysfunctional political climates might be countered by access to relevant resources (Abbas, Raja, Darr, \& Bouckenooghe, 2014; Bouckenooghe, 2012). Consistent with the JD-R model, we theorize that openness to experience and affective commitment to change, as personal resources, 
mitigate the likelihood that employees respond to POC with reduced trust in top management. Our findings support these theoretical arguments. This study thereby offers significant insights for organizational research and practice, by highlighting an important challenge associated with maintaining positive relationships between employees and organizational authorities, as well as identifying ways that this challenge can be resolved.

The direct negative effect of employees' POC on trust mirrors findings from previous research about the harmful effects of destructive political maneuvers on positive work attitudes and behaviors (Crawford et al., 2010; Rosen et al., 2014; Vigoda, 2000; Zhou \& Ferris, 1995). This negative relationship seemingly arises because employees interpret compliance-oriented climates as counterproductive and disrespectful (Ferris \& Kacmar, 1992). Even if strict compliance with the current organizational situation might not be harmful automatically, such as when organizations operate in stable external environments (Jiao, Alon, Koo, \& Cui, 2013), perceptions that the status quo is preferred over personal initiative tend to be counterproductive, in that they undermine employees' beliefs that they have the discretion to improve their current job situations or learn from their work efforts (Grimland et al., 2012; Kramer, 1999). In addition, negative feelings of frustration or anger that emerge in response to political decision making that thwarts employee initiative (Chang et al., 2009; Kacmar \& Ferris, 1993) may fuel beliefs that top management is withholding critical information and does not have the best interests of employees at heart.

Yet this negative effect of POC on trust can be mitigated by employees' tendency to search for and engage in new experiences (McCrae \& Costa, 1997), as well as by the value that they attribute to change for effective organizational functioning (Herscovitch \& Meyer, 2002). These two personal resources enhance the likelihood that employees can find creative ways to 
deal with an organizational climate in which personal initiative is curtailed by a preference for the status quo, which in turn mitigates the stress resulting from such an unfavorable work situation (Bakker et al., 2005; Kacmar \& Ferris, 1993). Ultimately, their propensity to express reduced trust in top management then may diminish. Moreover, these resources can fuel the joy that employees experience when they seek to improve their current job situation. Employees who score high on openness to experience or affective commitment to change may feel energized when they encounter and overcome an adverse situation, such as one that promotes covert politics (McCrae \& Costa, 1997; Meyer \& Herscovitch, 2001). Consistent with the JD-R model, this feeling reduces the likelihood that they develop negative feelings toward top management (Bakker \& Demerouti, 2007; Pooja et al., 2016).

Interestingly, Table 1 indicates non-significant correlation coefficients between the independent variable (POC) and the two moderators (openness to experience and affective commitment change), which mitigates concerns about the presence of multicollinearity or high shared variances among these variables. Moreover, the lack of a significant correlation and relationship between employees' openness to experience and trust in top management shows that a personality trait such as openness does not directly influence employees' attitudes toward their organization's top management but rather plays a more indirect role by influencing their attitudinal responses to adverse organizational climates. Notably, our theoretical focus on the buffering roles of both openness to experience and affective commitment to change revolves around the incremental role of POC in reducing trust. We thus offer organizations better insights into the conditions in which a culture marked by yea-saying is less likely to reduce trust in top management. Empirically, these buffering roles are supported by the slope differences that appear at different levels of the moderators. The interaction plots in Figures 2 and 3, and the 
corresponding simple slope analyses, indicate that increasing levels of POC do not contribute significantly to lowered trust in top management when employees are curious and seek out new experiences or believe in the intrinsic value of change for their organization. Thus, the belief that the organization favors strict compliance over personal initiative harms employees’ trust in top management only when those employees have limited access to these personal resources.

The theoretical focus of this study was on assessing slope differences at different levels of the study's moderators — as informed by the JD-R logic regarding the buffering effects of personal resources on how employees react to stress-inducing organizational climates (Bakker \& Demerouti, 2007)—not on comparing the actual values of employees' trust in top management at different levels of the independent and moderating variables. Nonetheless, one could argue for the likely presence of higher trust levels when workplace adversity is minimal (i.e., low organizational compliance) and personal resources are abundant (i.e., high openness to experience and high affective commitment to change). Yet the patterns in Figures 2 and 3 indicate a far more complex dynamic. First, when POC is low, trust in top management seems to be higher among employees who score low on openness to experience and affective commitment to change. A possible explanation is that when personal initiative is encouraged by the organization and employees tend to be complacent with regard to change (i.e., have a low natural tendency to experiment or do not see value in organizational change), they might over-rely on top management to tell them what to do. Second, Figures 2 and 3 indicate that when POC is high, trust in top management is higher among employees with high levels of openness to experience and affective commitment to change. Perhaps employees need to be able to draw from a minimum level of positive energy_derived from their personality or general attitudes toward change - that makes them confident that they can alter the status quo and maintain some 
trust in top management when their organization makes it challenging to take personal initiative. These post hoc explanations are highly speculative though; further studies might theorize, for example, how the relative usefulness of energy-enhancing personal resources, such as the ones studied herein, influence employees’ attitudes toward top management, depending on their perceptions of their surrounding organizational environment.

\section{Managerial Implications}

This study also has important practical implications. The belief that the organizational climate discourages employees from rocking the boat can be a significant source of stress. In response, organizations should seek strategies to diminish the occurrence of POC. Some employees may be hesitant to report cases in which their personal opinions have been ignored in such cultures, to avoid potential negative repercussions from powerful others (Barry \& Wilkinson, 2016). Organizations therefore must be proactive in identifying and resolving situations that prevent employees from speaking up about how to improve the status quo. For example, to the extent that the organization's historical functioning has created a culture that encourages covert political behaviors that favor the status quo, targeted development programs should stimulate employees to speak out frankly about organizational malfunctioning, even if these efforts challenge current power structures (Vredenburgh \& Shea-VanFossen, 2010). In the absence of such measures, the frustration that employees experience about not being able to improve their job situation may translate into negative feelings and ultimately lead them to distrust top management.

Employees’ openness to experience is another tool that organizational decision makers can leverage to mitigate frustration with a culture that thwarts personal initiative. Organizations marked by compliance-based climates can benefit from recruiting employees who score high on 
openness to experience and feel motivated to learn about new experiences and who are likely to come up with novel solutions to improve the organizational status quo despite strong resistance (McCrae \& Costa, 1997). Moreover, affective commitment to change is another lever for organizations that seek to mitigate problems associated with a political culture that focuses on the status quo. Organizations marked by compliance and yea-saying can benefit from hiring employees who believe that organizational change serves an important purpose and is key to the organization's long-term success. Notably, employees’ affective commitment to change is not set in stone; it can be developed through targeted initiatives. For example, employees might grow more motivated to support change in their organization to the extent that they enjoy higher levels of job security (Chawla \& Kelloway, 2004) or perceive less conflict among their different job roles (Iverson, 1996).

\section{Limitations and Future Research}

Some shortcomings of this study suggest research opportunities. First, our theoretical arguments about the negative relationship between employees’ perceptions about a climate that values strict compliance with the status quo and their trust in top management is based on the assumption that an organization-wide adherence to existing power structures is inherently dysfunctional. Although it might not be the case in all organizations, especially if their industrial context is stable and predictable (Jiao et al., 2013), political climates that stifle employee input about possible job improvements, even if incremental, tend to be perceived as counterproductive by employees, because such climates hamper their personal growth and career advancement (Byrne, 2005; Grimland et al., 2012). Nonetheless, future research might test our proposed framework across a wider set of organizations, to address the potential variance in the perceived 
usefulness of personal initiative, according to external competitive influences. Such research could also collect informative employee data about the actual or perceived need for change.

Second, we considered two specific contingency factors but ignored alternative potential buffers of the negative relationship between POC and trust in top management. For example, other personal characteristics could function as buffers too, such as employees' creative selfefficacy (Tierney \& Farmer, 2002) or resilience, which reflects their ability to bounce back from adverse situations that constrain their personal initiative (Youssef \& Luthans, 2007). Additional contextual factors also could influence the likelihood that a compliance-based climate leads to reduced levels of trust in top management, such as whether employees believe they are fairly rewarded for their job efforts (Colquitt, Conlon, Wesson, Porter, \& Ng, 2001) or whether they share their employer’s goals (Nahapiet \& Ghoshal, 1998).

Third, an empirical limitation of this study pertains to our reliance on students of an executive education program, who represent only a small proportion of the total workforce and may possess better-than-average personal resources, as suggested by their relatively high scores on the openness to experience and affective commitment to change constructs. Although these restricted response ranges actually provide a more conservative statistical test of the theoretical relationships (i.e., we find significant moderating effect relationships despite this restriction), additional studies should include a more diverse set of employees to assess the generalizability of the reported findings.

Fourth, another empirical limitation pertains to our focus on organizations that are based in one specific country (Pakistan); cultural factors cannot be excluded. Our theoretical arguments are not country specific, but Pakistani culture tends to be more risk averse than that of many Western countries (Hofstede, 2001), so employees may be hesitant to go out of their way to 
change or improve their job situation in the presence of an organizational climate that focuses on the status quo. In turn, the usefulness of change-supportive resources for reducing the negative effects of a compliance-oriented climate on trust in top management might be more salient in our study context than it would be in more risk-prone countries. Moreover, Pakistan reveals an intermediate score on the power distance construct, or general attitudes about whether members of societies can be unequal (Hofstede, 2001). This cultural dimension may influence the extent to which employees experience a compliance-oriented organizational climate as appropriate or stressful. Cross-country studies therefore might compare the relative importance of POC, in terms of defining how employees feel about top management and the potency of the underlying moderators, across different cultural contexts. Moreover, future studies could compare the role of relevant cultural values, such as power distance, at the individual level (Daniels \& Greguras, 2014) to investigate their potential role as moderators of the relationship between POC and trust in top management.

Finally, an important empirical limitation pertains to the reliability values for the focal constructs. Their Cronbach's alpha values range between .70 and .73 , such that they meet or exceed the well-established cut-off of .70 (Nunnally, 1978), yet they admittedly are relatively low. McCrae, Kurtz, Yamagata, and Terracciano (2011) recommend interpreting Cronbach’s alpha values in relation to values found in similar empirical settings. For example, previous cross-cultural studies indicate that the reliability of scales that measure the Big Five personality traits and affective commitment to change tend to be lowest in developing countries (Allik \& McCrae, 2004; Bouckenooghe, 2012; Kwantes, 2003; Schmitt, Allik, McCrae, \& BenetMartinez, 2007; Yilmaz, Ozer, \& Gunluk, 2014) ${ }^{6}$ Notably, low reliabilities tend to attenuate the

\footnotetext{
${ }^{6}$ The Cronbach's alpha values in our study are comparable with those reported in previous studies that took place in similar contexts. For example, trust in management evokes reliability values ranging between .76 and .79
} 
estimates of relationships between variables in regression analysis (Schmitt, 1996). That is, in the presence of lower reliabilities, any relationships between a focal variable and other variables may be underestimated because of the relative high random measurement error, which may lead to a failure to find true significant effects. Accordingly, studies that find significant effects, despite the relatively low reliabilities, arguably provide a more conservative statistical test of hypothesized relationships. Nonetheless, we consider the low reliabilities a potential weakness of this study, which suggests the need to establish the replicability of the results, which may reflect some "random noise" in the measurement scales. In particular, continued studies might replicate our test of the conceptual framework in contexts that are similar to and different from the context we study, to determine if the low reliabilities might be due to a specific country setting, sample size, or limited number of scale items. Another option could be to apply scales that may be less prone to random measurement error (Lattin, Carroll, \& Green, 2003; Warner, 2013).

\section{Conclusion}

This study has investigated how employees' perceptions of organizational climates that favor strict compliance over personal initiative spur negative feelings toward top management, in the form of reduced trust. The likelihood that POC leads to lower trust in top management decreases when employees can draw from the personal resources of openness to experience or affective commitment to change. These resources reduce employees’ frustration with the limited opportunities for improving their job situation in a compliance-oriented climate, because they are more likely to go out of their way to pursue positive organizational change. Overall, this study introduces a platform for further investigations of how organizations can mitigate the challenges

(Bouckenooghe, 2012; Bouckenooghe et al., 2009); perceptions of organizational politics reveal reliability values ranging between .67 and .73 (Byrne, 2005; Samad, 2011; Yilmaz et al., 2014); openness to experience scores an average reliability value of .76 across 56 countries, with several values below .60 (Schmitt et al., 2007); and affective commitment has reliability values of .73 in Bhatnagar (2007) and .75 in Kwantes (2003). 
that result from constraining political climates that promote the status quo, such that they can better avoid the development of negative feelings in their employee bases. 


\section{References}

Abbas, M., Raja, U., Darr, W., \& Bouckenooghe, D. (2014). Combined effects of perceived politics and psychological capital on job satisfaction, turnover intentions, and performance. Journal of Management, 40, 1813-1830.

Aiken, L.S., \& West, S.G. (1991). Multiple regression: Testing and interpreting interactions. Newbury Park, CA: Sage.

Aloe, A.M., \& Becker, B.J. (2012). An effect size for regression predictors in meta-analysis. Journal of Educational and Behavioral Statistics, 37, 278-297.

Allik, J., \& McCrae, R.R. (2004). Towards a geography of personality traits: Patterns of profiles across 36 cultures. Journal of Cross-Cultural Psychology, 35, 13-28.

Anderson, J.C., \& Gerbing, D.W. (1988). Structural equation modeling in practice: A review and recommended two-step approach. Psychology Bulletin, 1033: 411-423.

Arbuckle, J. (1997). Amos users' guide, version 3.6, Chicago IL: Smallwaters Corporation.

Baer, M., \& Oldham, G.R. (2006). The curvilinear relation between experienced creative time pressure and creativity: Moderating effects of openness to experience and support for creativity. Journal of Applied Psychology, 91, 963-970.

Bakker, A.B., \& Demerouti, E. (2007). The job demands-resources model: State of the art. Journal of Managerial Psychology, 22, 309-328.

Bakker, A. B., Demerouti, E., \& Euwema, M. C. (2005). Job resources may buffer the impact of job demands on burnout. Journal of Occupational Health Psychology, 10, 170-180.

Barrick, M. R., \& Mount, M. K. (1991). The big five personality dimensions and job performance: A meta-analysis. Personnel Psychology, 44, 1-26.

Barry, M., \& Wilkinson, A. (2016). Pro-social or pro-management? A critique of the conception of employee voice as a pro-social behaviour within organizational behaviour. British Journal of Industrial Relations, 54, 261-284.

Baum, J.R., \& Locke, E.A. (2004). The relationship of entrepreneurial traits, skill, and motivation to subsequent venture growth. Journal of Applied Psychology, 89, 587-598.

Bentler, P. M. (1995). EQS structural equations program manual. Encino, CA: Multivariate Software.

Bentler, P.M., \& Bonnett, D.G (1980). Significance tests and goodness of fit in the analysis of covariance structures. Psychological Bulletin, 88, 588-606.

Bhatnagar, J. (2007). Predictors of organizational commitment in India: Strategic HR roles, organizational learning capability and psychological empowerment, International Journal of Cross Cultural Management, 18, 1782-1811.

Blass, F.R., Brouer, R.L., Perrewe, P.L., \& Ferris, G.R. (2007). Politics understanding and networking ability as a function of mentoring: The roles of gender and race. Journal of Leadership \& Organizational Studies, 14, 93-105.

Bosco, F.A., Aguinis, H., Singh, K., Field, J.G., \& Pierce, C.A. (2015). Correlational effect size benchmarks. Journal of Applied Psychology, 100, 431-449.

Bouckenooghe, D (2012). The role of organizational politics, contextual resources, and formal communication on change recipients' affective commitment to change: a multilevel study. European Journal of Work and Organizational Psychology, 21, 575-602.

Bouckenooghe, D., De Clercq, D., \& Deprez, J. (2014). Interpersonal justice, relational conflict, and commitment to change: The moderating role of social interaction. Applied Psychology: An International Review, 63, 509-540. 
Bouckenooghe, D., Devos, G., \& Van den Broeck, H. (2009). Organizational change questionnaire - climate of change, processes, and readiness: Development of a new instrument. The Journal of Psychology, 143, 559-599.

Bouckenooghe, D., \& Menguc, B. (2016). Understanding the dynamics between supervisorfollower social capital, work engagement, and employees' creative work involvement. Canadian Journal of Administrative Sciences, doi.org/10.1002/cjas.1427.

Brockner, J., Siegel, P. A., Daly, J. P., Tyler, T., \& Martin, C. (1997). When trust matters: The moderating effect of outcome favorability. Administrative Science Quarterly, 42, 558-583.

Bryant, F.B., \& Yarnold P.R. (1995). Principal component analysis and exploratory and confirmatory factor analysis. In L.G. Grimm, \& R.R. Yarnold (Eds.), Reading and understanding multivariate statistics (pp. 99-136). Washington DC: American Psychological Association.

Byrne, Z.S. (2005). Fairness reduces the negative effects of organizational politics on turnover intentions, citizenship behavior and job performance. Journal of Business and Psychology, 20, 175-200.

Chang, C.-H., Rosen, C.C., \& Levy, P.E. (2009). The relationship between perceptions of organizational politics and employee attitudes, strain, and behavior: A meta-analytic examination. Academy of Management Journal, 52, 779-801.

Chang, C.-H., Rosen, C.C., Siemieniec, G.M., \& Johnson, R.E. (2012). Perceptions of organizational politics and employee citizenship behaviors: Conscientiousness and selfmonitoring as moderators. Journal of Business and Psychology, 27, 395-406.

Chawla, A., \& Kelloway, K. (2004). Predicting openness and affective commitment to change. Leadership and Organization Development Journal, 25, 485-498.

Chen, C.-H.V., \& Indartono, S. (2011). Study of commitment antecedents: The dynamic point of view. Journal of Business Ethics, 103, 529-541.

Chen, G., Liu, C., \& Tjosvold, D. (2005). Conflict management for effective top management teams and innovation in China. Journal of Management Studies, 42, 277-300.

Chen, Y.-Y., \& Fang, W. (2008). The moderating effect of impression management on the organizational politics-performance relationship. Journal of Business Ethics, 79, 263-277.

Choi, M. (2011). Employees’ attitudes toward organizational change: A literature review. Human Resource Management, 50, 479-500.

Chughtai, A.A., \& Buckley, F. (2013). Exploring the impact of trust on research scientists' work engagement. Personnel Review, 42, 396-421.

Clapp-Smith, R., Vogelgesang, G.R., \& Avey, J.B. (2009). Authentic leadership and positive psychological capital: The mediating role of trust at the group level of analysis. Journal of Leadership \& Organizational Studies, 15, 227-239.

Cohen, S. \& Wills, T. A. (1985). Stress, social support, and the buffering hypothesis. Psychological Bulletin, 98, 310-357.

Colquitt, J.A., Conlon, D.E., Wesson, M.J., Porter, C.O.L.H., \& Ng, K.Y. (2001). Justice at the millennium: A meta-analytic review of 25 years of organizational justice research. Journal of Applied Psychology, 86, 425-445.

Colquitt, J.A., \& Rodell, J.B. (2011). Justice, trust, and trustworthiness: A longitudinal analysis integrating three theoretical perspectives. Academy of Management Journal, 54, 11831206. 
Colquitt, J.A., Scott, B.A., \& Lepine, J.A. (2007). Trust, trustworthiness, and trust propensity: A meta-analytic test of their unique relationships with risk taking and job performance.

Journal of Applied Psychology, 92, 909-927.

Costigan, R.D., Insinga, R.C., Berman, J.J., Kranas, G., \& Kureshov, V.A. (2011). Revisiting the relationship of supervisor trust and CEO trust to turnover intentions: A three-country comparative study. Journal of World Business, 46, 74-83.

Crawford, E. R., LePine, J. A., \& Rich, B. L. (2010). Linking job demands and resources to employee engagement and burnout: A theoretical extension and meta-analytic test. Journal of Applied Psychology, 93, 834-848.

Cropanzano, R., Howes, J.C., Grandey, A.A., \& Toth, P. (1997). The relationship of organizational politics and support to work behaviors, attitudes, and stress. Journal of Organizational Behavior, 18, 159-180.

Cummings, L.L. \& Bromily, P. (1996). The organizational trust inventory (OTI): Development \& validation. In Kramer, R. and Tyler, T. (Eds.), Trust in organizations (pp. 302-330), Sage, Thousand Oaks, CA.

Daniels, M.A., \& Greguras, G.J. (2014). Exploring the nature of power distance: Implications for micro- and macro-level theories, processes, and outcomes. Journal of Management, 14, 1202-1229.

De Clercq, D., Bouckenooghe, D., Raja, U., \& Matsyborska, G. (2014). Servant leadership and work engagement: The contingency effects of leader-follower social capital. Human Resource Development Quarterly, 25, 183-212.

De Clercq, D., Haq, I.U., \& Azeem, M.U. (2018). Self-efficacy to spur job performance: Roles of job-related anxiety and perceived workplace incivility. Management Decision, 56, 891907.

De Clercq, D., Thongpapanl, N., \& Dimov, D. (2009). When good conflict gets better and bad conflict becomes worse: The role of social capital in the conflict-innovation relationship. Journal of the Academy of Marketing Science, 37, 283-297.

Dempster, A.P., Laird, N.M., \& Rubin, D.B. (1977). Maximum likelihood estimation from incomplete data via the EM algorithm. Journal of the Royal Statistical Society Series B, 39, $1-38$

Eisenhardt, K.M., \& Bourgeois, L.J. (1988). Politics of strategic decision making in highvelocity environments. Academy of Management Journal, 32, 543-576.

Espedal, B. (2017). Understanding how balancing autonomy and power might occur in leading organizational change. European Management Journal, 35, 155-163.

Fan, X., Thompson, B., \& Wang, L. (1999). The effects of sample size, estimation methods, and model specification on SEM fit indices. Structural Equation Modeling: A Multidisciplinary Journal, 6, 56-83.

Ferris, G. R., \& Kacmar, K. M. (1992). Perceptions of organizational politics. Journal of Management, 18, 93-116.

Frost, P.J., \& Egri, C.P. (1991). The political process of innovation. In B.M. Staw \& L.L. Cummings (Eds.), Research in organizational behavior. Vol. 13 (pp. 229-295), Greenwich, CT: JAI Press.

Gao, S., Mokhtarian, P., \& Johnston, R. (2014). Nonnormality of data in structural equation models. Transportation Research Record: Journal of the Transportation Research Board, 2082, 116-124. 
George, J. M., \& Zhou, J. (2001). When openness to experience and conscientiousness are related to creative behavior: An interactional approach. Journal of Applied Psychology, 86, 513-524.

Grimland, S., Vigoda-Gadot, E., \& Baruch, Y. (2012). Career attitudes and success of managers: the impact of chance event, protean, and traditional careers. International Journal of Human Resource Management, 23, 1074-1094.

Hakanen, J. J., Schaufeli, W. B., \& Ahola, K. (2008). The job demands-resources model: A three-year cross-lagged study of burnout, depression, commitment, and work engagement. Work \& Stress, 22, 224-241.

Herscovitch, L., \& Meyer, J. P. (2002). Commitment to organizational change: Extension of a three component model. Journal of Applied Psychology, 87, 474-487.

Hochwarter, W. A., Witt, L. A., \& Kacmar, K. M. (2000). Perceptions of organizational politics as a moderator of the relationship between conscientiousness and job performance. Journal of Applied Psychology, 85, 472-478.

Hofstede, G. (2001). Culture's consequences: Comparing values, behaviors, institutions and organizations across nations, 2d ed. Thousand Oaks, CA: Sage Publications.

Holland, P., Cooper, B.K. Pyman, A., \& Teicher, J. (2012). Trust in management: the role of employee voice arrangements and perceived managerial opposition to unions. Human Resource Management Journal, 22, 377-391.

Hu, L.T., \& Bentler, P.M. (1998). Fit indices in covariance structure modeling: Sensitivity to underparameterized model misspecification. Psychological Methods, 3, 424-453.

Hurley, R.F. (2006). The decision to trust. Harvard Business Review, 84, 55-62.

Iverson, R.D. (1996). Employee acceptance of organizational change: The role of organizational commitment. International Journal of Human Resource Management, 7, 122-149.

Jackson, D.L. (2007). The effect of the number of observations per parameter in misspecified confirmatory factor analytic models. Structural Equation Modeling, 14, 48-76.

Jackson, D.L., Gillaspy, J.A., \& Purc-Stephenson, R. (2009). Reporting practices in confirmatory factor analysis: An overview and some recommendations. Psychological Methods, 14, 623.

Jiao, H., Alon, I., Koo, C.K., \&Cui, Y. (2013).When should organizational change be implemented? The moderating effect of environmental dynamism between dynamic capabilities and new venture performance. Journal of Engineering and Technology Management, 30, 188-205.

John, O.P., Donahue, E.M., \& Kentle, R.L. 1991. The “Big Five” inventory-versions 4a and 5a. Berkley: Institute of Personality and Social Research, University of California, Berkley.

Joreskog, K.G., \& Sorbom, D. (1986). LISREL VI: Analysis of linear structural relationships by maximum likelihood and least squares methods. Mooresville, IN: Scientific Software.

Kabanoff, B., Waldersee, R., \& Cohen, M. (1995). Espoused values and organizational change themes. Academy of Management Journal, 38, 1075-1104.

Kacmar, K.M., \& Baron, R. A. (1999). Organizational politics: The state of the field, links to related processes, and an agenda for future research. In G.R. Ferris (Ed.), Research in personnel and human resources management (pp. 1-40). Stamford, CT: JAI Press.

Kacmar, K.M., \& Carlson, D.S. (1997). Further validation of the perceptions of politics scale (POPS): A multiple sample investigation. Journal of Management, 23, 627-658. 
Kacmar, K.M., \& Ferris, G. R. (1991). Perceptions of organizational politics scale (POPS): Development and construct validation. Educational and Psychological Measurement, 51, 193-205.

Kacmar, K.M., \& Ferris, G.R. (1993). Politics at work: Sharpening the focus of political behavior in organizations. Business Horizons, 36, 70-74.

Keller, T., \& Weibler, J. (2015). What it takes and costs to be an ambidextrous manager: Linking leadership and cognitive strain to balancing exploration and exploitation. Journal of Leadership \& Organizational Studies, 22, 54-71.

Korsgaard, M.A., Schweiger, D.M., \& Sapienza, H.J. (1995). Building commitment, attachment, and trust in strategic decision-making teams: The role of procedural justice. Academy of Management Journal, 38, 60-84.

Kramer, R.M. (1999). Trust and distrust in organizations: Emerging perspectives, enduring questions. Annual Review of Psychology, 50, 569-598.

Kwantes, C.T. (2003). Organizational citizenship and withdrawal behaviors in the USA and India: Does commitment make a difference? International Journal of Cross Cultural Management, 3, 5-26.

Lambert, E., Hogan, N., Baron-Bellessa, S., \& Jiang, S. (2012). Examining the relationship between supervisor and management trust and job burnout among correctional staff. Criminal Justice and Behavior, 39, 938-957.

Lattin, J.M., Carroll, J.D., \& Green, P.E. (2003). Analyzing multivariate data. Belmont, CA: Thomson Brooks/Cole.

Lee, D., Kim, K., Kim, T.G., Kwon, S., \& Cho, B. (2013). How and when organizational integration efforts matter in South Korea: a psychological process perspective on the postmerger integration. International Journal of Human Resource Management, 24, 944-965.

Leung, D., Wong, E., Chan, S., \& Lam, T.H. (2013). Psychometric properties of the Big Five Inventory in a Chinese sample of smokers receiving cessation treatment: A validation study. Journal of Nursing Education and Practice, 3(6), 1-10.

Lewicki, R.J., Tomlinson, E.C. \& Gillespie, N. (2006). Models of interpersonal trust development: Theoretical approaches, empirical evidence and future directions. Journal of Management, 32, 992-1022.

Li, J., Wu, L.-Z., Liu, D., Kwan, H.K., \& Liu, J. (2014). Insiders maintain voice: A psychological safety model of organizational politics. Asia Pacific Journal of Management, 31, 853-874.

Little, R.J.A., \& Rubin, D.B. (1989). The analysis of social science data with missing values. Sociological Methods and Research, 18, 292-326.

Little, R.J.A., \& Schenker, N. (1995). Missing data. In G. Arminger, C. Clogg, \& M. Sobel (Eds.), Handbook of statistical modeling for the social and behavioral sciences (pp. 39-75). New York: Plenum Press.

Liu, J., Siu, O.L., \& Shi, K. (2010). Transformational leadership and employee well-being: the mediating role of trust in the leader and self-efficacy. Applied Psychology: An International Review, 59, 454-479.

Macky, K., \& Boxall, P. (2007). The relationship between 'high-performance work practices' and employee attitudes: an investigation of additive and interaction effects. International Journal of Human Resource Management, 18, 537-567. 
Magner, N., \& Staley, A.B. (2014). Roles of instrumental and noninstrumental voice in members' reactions toward interorganizational committees. International Journal of Organization Theory and Behavior, 17, 311-334.

Mahajan, A., Bishop, J.W., \& Scott, D. (2012). Does trust in top management mediate top management communication, employee involvement and organizational commitment relationships? Journal of Managerial Issues, 24, 173-190.

Marsh, H.W., Balla, J.R., \& Hau, K.T. (1996). An evaluation of incremental fit indices: A clarification of mathematical and empirical properties. In G.A. Marcoulides \& R.E. Schumacker, (Eds.), Advanced structural equation modeling: Issues and techniques. Mahwah, NJ: Erlbaum.

Mayer, R.C., \& Davis, J.H. (1999). The effect of performance appraisal system on trust for management: A field quasi-experiment. Journal of Applied Psychology, 84, 123-136.

Mayer, R.C., Davis, J.H., \& Schoorman, F.D. (1995). An integrative model of organizational trust. Academy of Management Review, 20, 709-734.

McCauley, D.P. \& Kuhnert, K.W. (1992). A theoretical review and empirical investigation of employee trust in management. Public Administration Quarterly, 16, 265-282.

McCrae, R. R. (1987). Creativity, divergent thinking, and openness to experience. Journal of Personality and Social Psychology, 52, 1258-1265.

McCrae, R.R. (1984). Openness to experience: Expanding the boundaries of Factor V. European Journal of Personality, 8(4), 251-272.

McCrae, R.R., \& Costa, P.T. (1997). Conceptions and correlates of openness to experience. In R. Hogan, J. Johnson, \& S. Briggs (Eds.), Handbook of personality psychology (pp. 825-847). San Diego, CA: Academic Press.

McCrae, R., Kurtz, J.E., Yamagata, S., \& Terracciano, A. (2011). Internal consistency, retest reliability, and their implications for personality scale validity. Personality and Social Psychology Review, 15, 28-50.

Meyer, J.P., \& Herscovitch L. (2001). Commitment in the workplace: Toward a general model. Human Resource Management Review, 11, 299-326.

Michaelis, B., Stegmaier, R., \& Sonntag, K. (2009). Affective commitment to change and innovation implementation behavior: The role of charismatic leadership and employees' trust in top management. Journal of Change Management, 9, 399-417.

Miller, B.K., Rutherford, M.A., \& Kolodinsky, R.W. 2008. Perceptions of organizational politics: A meta-analysis of outcomes. Journal of Business and Psychology, 22, 209-222.

Nahapiet, J., \& Ghoshal, S., (1998). Social capital, intellectual capital, and the organizational advantage. Academy of Management Review, 23, 242-268.

Neves, P., \& Caetano, A. (2009). Affective commitment to change: Contributions to trust in the supervisor and work outcomes. Group \& Organization Management, 34, 623-644.

Nienaber, A.-M., Romeike, P.D., Searle, R., \& Schewe, G. (2015). A qualitative meta-analysis of trust in supervisor-subordinate relationships. Journal of Managerial Psychology, 30, 507534.

Nunnally, J.C. (1978). Psychometric theory, $2^{\text {nd }}$ edition. New York: McGraw-Hill.

O’Connor, W.E., \& Morrison, T.G. (2001). A comparison of situational and dispositional predictors of perceptions of organizational politics. The Journal of Psychology, 135, 301312.

Parker, C.P., Dipboye, R.L., \& Jackson, S.L. (1995). Perceptions of organizational politics: An investigation of antecedents and consequences. Journal of Management, 5, 891-912. 
Podsakoff, P., MacKenzie, S., Lee, J., \& Podsakoff, N. (2003). Common method biases in behavioral research: A critical review of the literature and recommended remedies. Journal of Applied Psychology, 88, 879-903.

Podsakoff, P. M., \& Organ, D. W. (1986). Self-reports in organization research: Problems and prospects. Journal of Management, 12, 532-544.

Pooja, A.A., De Clercq, D., \& Belausteguigoitia, I. (2016). Job stressors and organizational citizenship behavior: The roles of organizational commitment and social interaction. Human Resource Development Quarterly, 27, 373-405.

Preacher, K.J., \& Hayes, A.F. (2004). SPSS and SAS procedures for estimating indirect effects in simple mediation models. Behavior Research Methods, Instruments, \& Computers, 36, 717-731.

Quinn, R.W., Spreitzer, G.M. \& Lam, C.F. (2012), "Building a sustainable model of human energy in organizations: Exploring the critical role of resources”, Academy of Management Annals, Vol. 6, pp. 337-396.

Raja, U., \& Johns, G. (2010). The joint effects of personality and job scope on in-role performance, citizenship behaviors, and creativity. Human Relations, 63, 981-1005.

Rosen, C.C., Ferris, D.L., Brown, D.J., Chen, Y., \& Yan, M. (2014). Perceptions of organizational politics: A need satisfaction paradigm. Organization Science, 25, 1026-1055.

Rousseau, D.M., Sitkin, S.B., Burt, R.S. \& Camerer, C. (1998). Not so different after all: A cross-discipline view of trust. Academy of Management Review, 23, 393-404.

Saksvik, I.B., \& Hetland, H. (2009). Exploring dispositional resistance to change. Journal of Leadership \& Organizational Studies, 16, 175-183.

Samad, S. (2011). Examining the effects of emotional intelligence on the relationship between organizational politics and job performance. International Journal of Business and Social Science, 2, 119-126.

Schafer, J. (1997). Analysis of incomplete multivariate data. London: Chapman \& Hall.

Schafer, J.L. (1999). Multiple imputation: A primer. Statistical Methods in Medical Research, 8, 3-15.

Schaufeli, W.B., \& Bakker, A.B. (2004). Job demands, job resources, and their relationship with burnout and engagement: A multi-sample study. Journal of Organizational Behavior, 25, 293-315.

Schmitt, N. (1996). Uses and abuses of coefficient alpha. Psychological Assessment, 8, 350-353.

Schmitt, D.P., Allik, J., McCrae, R.R., \& Benet-Martinez, V. (2007). The geographic distribution of Big Five personality traits: Patterns and profiles of human self-description across 56 nations. Journal of Cross Cultural Psychology, 38, 173-212.

Schmitz, C. \& Ganesan, S. (2014). Managing customer and organizational complexity in sales organizations. Journal of Marketing, 78, 59-77.

Schoorman, D.F., Mayer, R.C., Davis, J.M. (2007). An integrative model of organizational trust: past, present and future. Academy of Management Review, 32, 344-354.

Shen, J., Tang, N., \& D'Netto, B. (2014). A multilevel analysis of the effects of HR diversity management on employee knowledge sharing: The case of Chinese employees. International Journal of Human Resource Management, 25, 1720-1738.

Simons, T., \& Peterson, R.S. (2000). Task conflict and relationship conflict in top management teams: The pivotal role of intragroup trust. Journal of Applied Psychology, 83, 102-111.

Spector, P.E. (2006). Method variance in organizational research: Truth or urban legend? Organizational Research Methods, 9, 221-232. 
Spence, R., Owens, M., \& Goodyer, I. (2012). Item response theory and validity of the NEO-FFI in adolescents. Personality and Individual Differences, 53, 801-807.

Thomas, G.F., Zolin, R., \& Hartman, J.L. (2009). The central role of communication in developing trust and its effect on employee involvement. Journal of Business Communication, 46, 287-310.

Tierney, P., \& Farmer, S.M. (2002). Creative self-efficacy: Potential antecedents and relationship to creative performance. Academy of Management Journal, 45, 1137-1148.

Valle, M., \& Perewé, P.L. (2000). Do politics perception related to political behavior? Human Relations, 53, 359-386.

Van Dam, K., Oreg, S., \& Schyns, B. (2008). Daily work contexts and resistance to organisational change: The role of leader-member exchange, development climate, and change process characteristics. Applied Psychology: An International Review, 57, 313-334.

Van Doorn, R.R.A., \& Hülsheger, U.R. (2015). What makes employees resilient to job demands? The role of core self-evaluations in the relationship between job demands and strain reactions. European Journal of Work and Organizational Psychology, 24, 76-87.

Van Dyne, L., Ang, S., \& Botero, I.C. (2003). Conceptualizing employee silence and employee voice as multidimensional constructs. Journal of Management Studies, 40, 1359-1392.

van Emmerik, I.J.H., Bakker, A.B., \& Euwema, M.C. (2009). Explaining employees’ evaluations of organizational change with the job demands-resources model. Career Development Journal, 14, $594-613$.

Vigoda, E. (2000). Organizational politics, job attitudes, and work outcomes: Exploration and implications for the public sector. Journal of Vocational Behavior, 57, 326-347.

Vredenburgh, D., \& Shea-VanFossen, R. (2010). Human nature, organizational politics, and human resource development. Human Resource Development Review, 9, 26-47.

Wanberg, C. R., \& Banas, J. T. (2000). Predictors and outcomes of openness to changes in a reorganizing workplace. Journal of Applied Psychology, 85, 132-142.

Warner, R.M. (2013). Applied statistics (2d ed.) Thousand Oaks, CA: Sage.

Watson D., Suls, J., \& Haig, J. 2002. Global self-esteem in relation to structural models of personality and affectivity. Journal of Personality and Social Psychology. 83, 185-197.

Webber, S.S., Bishop, K., \& O’Neill, R. (2012). Trust repair: The impact of perceived organizational support and issue-selling. Journal of Management Development, 31, 724-737.

Wu, M., Huang, X., Li, C., \& Liu, W. (2011). Perceived interactional justice and trust-insupervisor as mediators for paternalistic leadership. Management and Organization Review, 8, 97-121.

Yilmaz, E., Ozer, G., \& Gunluk, M. (2014). Do organizational politics and organizational commitment affect the budgetary slack creation in publication organizations. Procedia Social and Behavioral Sciences, 150, 241-250.

Youssef, C. M., \& Luthans, F. (2007). Positive organizational behavior in the workplace: The impact of hope, optimism, and resiliency. Journal of Management, 33, 774-800.

Yuan, K.-H. (2005). Fit indices versus test statistics. Multivariate Behavioral Research, 40, 115148.

Zahra, S., \& Hayton, J.C. (2008). The effect of international venturing on firm performance: The moderating influence of absorptive capacity. Journal of Business Venturing, 23, 195-220.

Zhang, A.Y., Tsui, A.S., Song, L.J., Li, C., \& Jia, L. (2008). How do I trust thee? The employeeorganization relationship, supervisory support, and middle manager trust in the organization. Human Resource Management, 47, 111-132. 
Zhou, J., \& Ferris, G. R. (1995). The dimensions and consequences of organizational politics perceptions: A confirmatory analysis. Journal of Applied Social Psychology, 25, 17471764. 
Figure 1. Conceptual Model

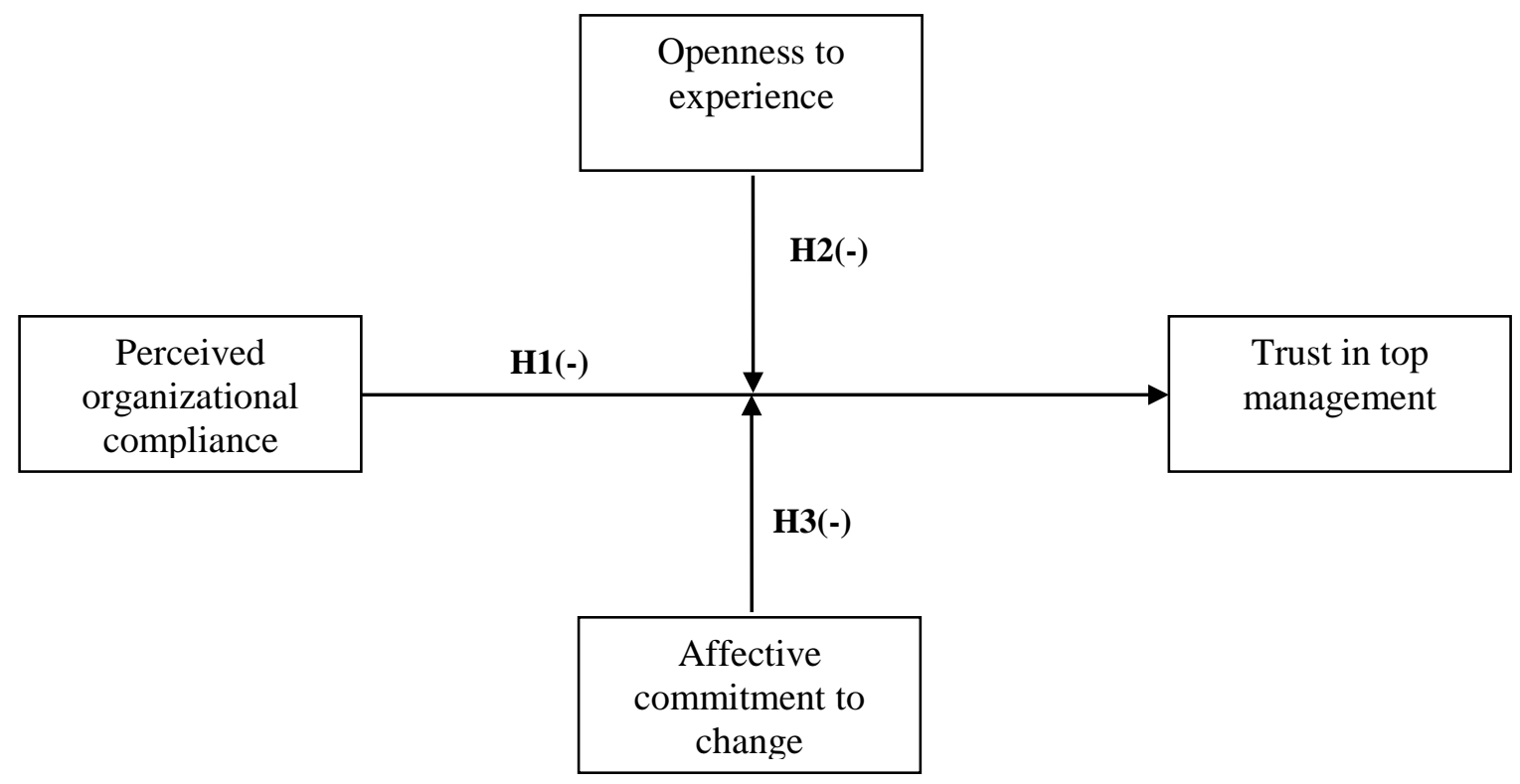


Figure 2. Moderating Effect of Openness to Experience on the POC-Trust in Top Management Relationship

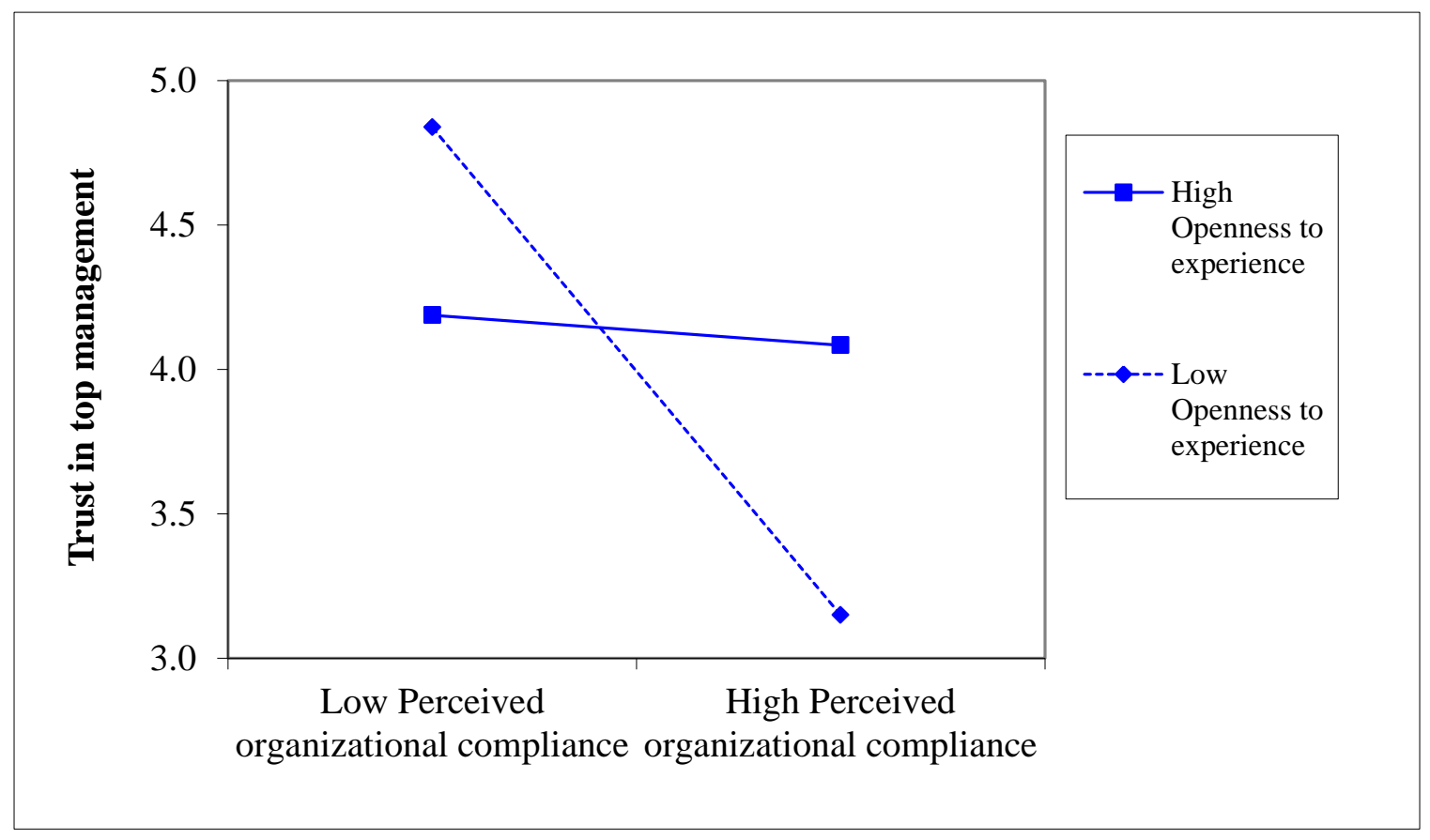


Figure 3. Moderating Effect of Affective Commitment to Change on the POC-Trust in Top Management Relationship

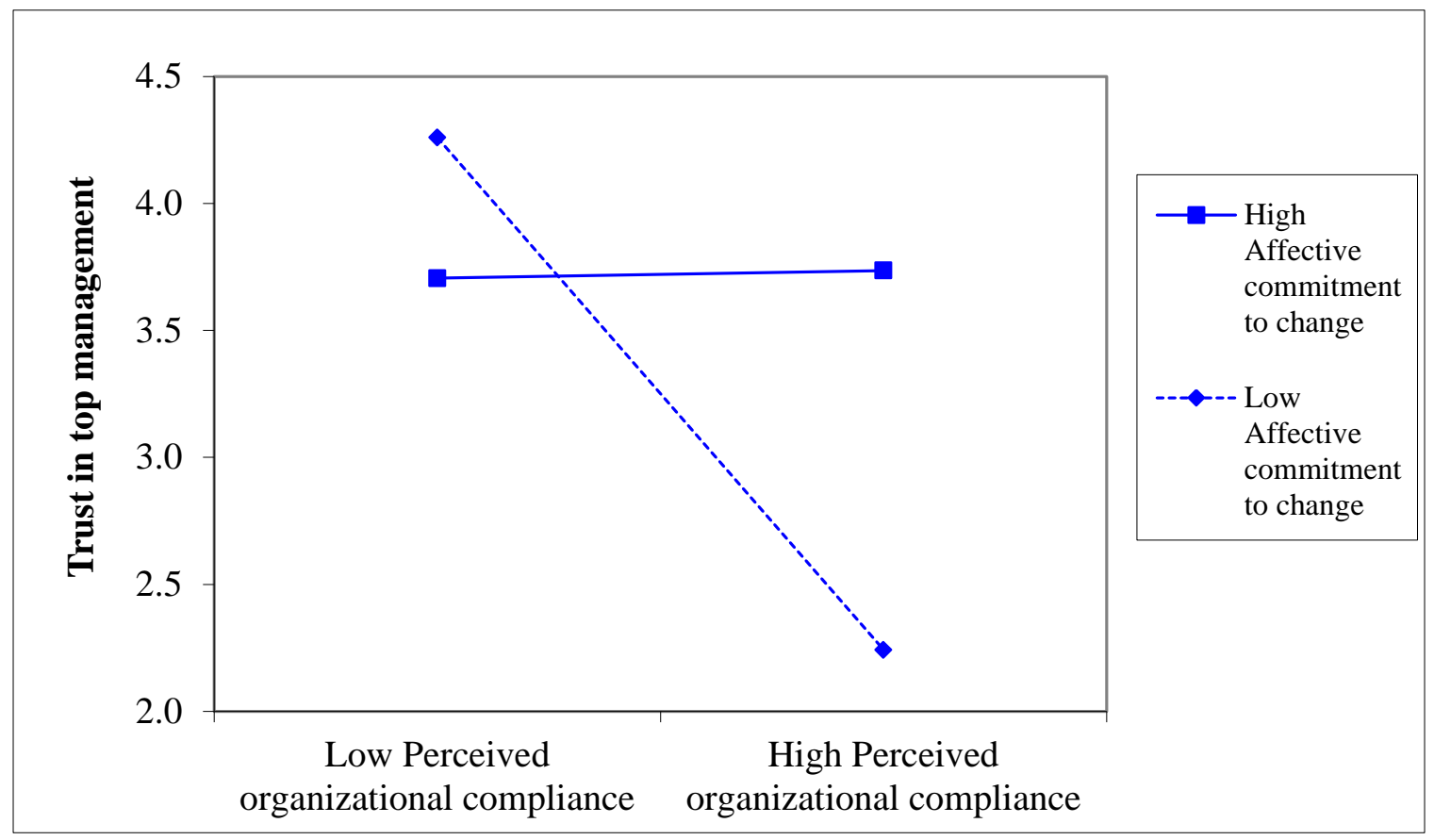


Table 1. Descriptive Statistics and Correlations

\begin{tabular}{|c|c|c|c|c|c|c|c|c|}
\hline & Mean & SD & 1 & 2 & 3 & 4 & 5 & 6 \\
\hline 1. Trust in top management & 3.84 & .71 & & & & & & \\
\hline 2. Perceived organizational compliance & 2.86 & .64 & $-.38^{* *}$ & & & & & \\
\hline 3. Openness to experience & 4.08 & .49 & .10 & -.10 & & & & \\
\hline 4. Affective commitment to change & 4.07 & .53 & $.24^{* *}$ & -.14 & $.18^{*}$ & & & \\
\hline 5. Age & 39.62 & 9.81 & .00 & $-.26^{* *}$ & $.24^{* *}$ & .08 & & \\
\hline 6. Organizational tenure & 9.85 & 7.09 & -.07 & $-.17^{*}$ & .15 & .03 & $.81^{* *}$ & \\
\hline 7. Organization type ( $1=$ textile $)$ & .31 & .47 & .08 & $.25^{* *}$ & $-.25^{* *}$ & -.07 & $-.64^{* *}$ & $-.58^{* *}$ \\
\hline
\end{tabular}

Notes: $\mathrm{N}=159$.

$* * p<.01 ; * p<.05$. 
Table 2. Regression Results (Dependent Variable: Trust in Top Management)

\begin{tabular}{|c|c|c|c|c|c|}
\hline & Model 1 & Model 2 & Model 3 & Model 4 & Model 5 \\
\hline Age & $.02^{\mathrm{a}}$ & .01 & .00 & -.00 & .01 \\
\hline Organizational tenure & -.02 & -.01 & -.01 & -.01 & -.01 \\
\hline Organization type ( 1 = textile) & .18 & $.28+$ & $.31 *$ & $.30 *$ & $.32 *$ \\
\hline $\mathrm{H}_{1}$ : Perceived organizational compliance (POC) & & $-.46^{* * *}$ & $-.43 * * *$ & $-.45 * * *$ & $-.50 * * *$ \\
\hline Openness to experience & & & .11 & .07 & .10 \\
\hline Affective commitment to change & & & $.25 *$ & $.24 *$ & $.24 *$ \\
\hline $\mathrm{H}_{2}:$ POC $\times$ Openness to experience & & & & $.40 *$ & \\
\hline $\mathrm{H}_{3}:$ POC $\times$ Affective commitment to change & & & & & $.51 * * *$ \\
\hline $\mathrm{R}^{2}$ & .02 & .18 & .22 & .25 & .27 \\
\hline $\mathrm{R}^{2}$ change & & $.16^{* * *}$ & $.04^{*}$ & $.03 *$ & $.05 * * *$ \\
\hline
\end{tabular}

Notes: $\mathrm{N}=159$; unstandardized coefficients (two-tailed $p$-values)..

${ }^{* * *} p<.001 ;{ }^{* *} p<.01 ;{ }^{*} p<.05$. 